\title{
Technology Addiction in Preschool Period: An Analysis on Illustrated Children's Books
}

\section{Okul Öncesi Dönemde Teknoloji Bağımlılığı: Resimli Çocuk Kitaplarına Yönelik Bir İnceleme}

\section{Tuğçe Güzelyurt ${ }^{1}$, Ömer Nayci}

\section{Keywords \\ 1.Preschool Period \\ 2.Technology Addiction \\ 3.Children's Literature \\ 4. Illustrated Children's Book}

Anahtar Kelimeler

1.Okul Öncesi Dönem

2.Teknoloji Bağımlılığı

3.Çocuk Edebiyatı

4.Resimli Çocuk Kitabı

Received/Başvuru Tarihi

19.04.2020

Accepted / Kabul Tarihi 30.09.2020

\begin{abstract}
In today's world, technological devices have started to take an important part in human life. Many studies have determined that technological devices have positive and negative effects on individuals' physical, social-emotional, cognitive, and language development. In parallel with the developments in science and technology, tools such as pens, books, notebooks, and erasers, which used to be popular in the past for children, have been replaced by devices such as tablets, phones, and computers. When examined from this aspect, it can be mentioned that many technology-based devices, which are widely used today, have positive and negative effects on people. Especially in early childhood, the misuse of technological devices can cause undesirable and permanent results. For this reason, families and stakeholders in the education process should provide awareness of the prevention of technology addiction. Illustrated children's books are one of the most important tools that parents and educators can use to convey accurate information to children. With the help of illustrated children's books, how and how long technological devices will be benefited, and problems that may arise in their misuse can be conveyed to children in accordance with their developmental levels. This situation reveals the requirement for the content and the way of conveying the content of illustrated children's books related to technology addiction to be correct. In parallel with this information, the study aimed to examine the content of illustrated children's books on technology addiction for the preschool period. The qualitative research method was used in the research. The study group was determined by the criterion sampling method, one of the purposeful sampling methods. Accordingly, the study group consisted of 15 illustrated children's books that are still in print and accessible to researchers. Illustrated children's books were examined by document analysis method. The books were analyzed using descriptive analysis technique and content analysis technique. As a result of the study, it was observed that the illustrated children's books examined did not contain enough content about the dangers that might be encountered in the internet environment which children are frequently exposed to, and some of the suggested solutions for technology addiction are considered appropriate, but not presented sufficiently. As in other books, illustrated children's books on technology addiction should be written according to the child's developmental characteristics, and an information note for families and information about the age group that the book addresses should be included for guidance. Besides, in these children's books, judgments that create anxiety, stress, and fear and blame the family or the child should be avoided.
\end{abstract}

Öz

Günümüzde teknolojik araçlar insan yaşamında önemli bir yer edinmeye başlamıştır. Teknolojik araçların bireylerin fiziksel, sosyal-duygusal, bilişsel ve dil gelişimine olumlu ve olumsuz etkisinin olduğu birçok araştırmayla belirlenmiştir. Bilim ve teknolojideki gelişmeler doğrultusunda çocuk açısından geçmişte popüler olan kalem, kitap, defter ve silgi gibi araç gereçlerin yerini tablet, telefon, bilgisayar gibi araçlar almıştır. Bu yönden incelendiğinde, günümüzde yaygın olarak kullanılan teknoloji odaklı birçok aracın insanlar üzerinde olumlu ve olumsuz sonuçlar meydana getirdiği söylenebilir. Özellikle erken çocukluk döneminde teknolojik araçların yanlış kullanımı istenmedik kalıcı sonuçlara sebep olabilmektedir. Bu nedenle aileler ve eğitim sürecinde yer alan paydaşlar teknoloji bağımlılı̆ının önlenmesi konusunda bilinçlendirilmelidir. Ailelerin ve eğitimcilerin çocuklara doğru bilgi aktarabilmeleri için kullanacakları en önemli araçlardan biri de resimli çocuk kitaplarıdır. Resimli çocuk kitapları aracılığıyla çocuklara teknolojik araçların nasıl, ne kadar süre kullanılacağı ve yanlış kullanımında oluşabilecek sorunlar çocukların gelişim düzeylerine uygun aktarılabilmektedir. Bu durum teknoloji bağımlılığı konusunu kapsayan resimli çocuk kitaplarının içeriğinin ve aktarılıs biçiminin doğru olması gerekliliğini ortaya koymaktadır. Bu bilgiler doğrultusunda çalışmanın amacı, okul öncesi döneme yönelik teknoloji bağımlılığı konusunu içeren resimli çocuk kitaplarının içeriğini incelemektir. Araştırmada nitel araştırma yöntemi kullanılmıştır. Çalışma grubu, amaçlı örnekleme yöntemlerinden ölçüt örnekleme yöntemiyle belirlenmiştir. Bu doğrultuda çalışma grubu, baskısı devam eden ve araştırmacıların ulaşabildiği 15 resimli çocuk kitabından oluşmuştur. Resimli çocuk kitapları doküman inceleme yöntemiyle incelenmiştir. Betimsel analiz ve içerik analizi tekniğiyle analiz edilmiştir. Araştırmanın sonucunda, incelenen resimli çocuk kitaplarında çocukların sıklıkla maruz kaldıkları internet ortamındaki tehlikeler konusunda yeterince içeriğe yer verilmediği, ayrıca teknoloji bağımlılığına ilişkin önerilen çözümlerin bazılarının uygun olmakla birlikte yeterli düzeyde verilmediği görülmüştür. Diğer kitaplarda olduğu gibi teknoloji bağımlılığı konulu resimli çocuk kitapları da çocuğun gelişim özelliklerine uygun şekilde yazılmalı, yol gösterici olması açısından ailelere yönelik bilgi notu ve kitabın hitap ettiği yaş grubuna ilişkin bilgilere yer verilmelidir. Bunların aynı sıra söz konusu çocuk kitaplarında kaygı, stres, korku yaratan ve aile ya da çocuğu suçlayan yargılardan kaçınılmalıdır.

${ }^{1}$ Corresponded Author, tugce.guzelyurt@hotmail.com, TÜRKiYE; https://orcid.org/0000-0002-6577-8257

${ }^{2}$ Şırnak University, Şırnak Vocational School, Child Care and Youth Services Division, Şırnak, TURKEY; https://orcid.org/0000-0002-6087-6456 


\section{INTRODUCTION}

The preschool period is considered the most critical period that affects personality development, the acquisition of knowledge, skills, and habits in the 0-72-month period, and directly affects the later years of life (Akduman, 2011). In this period, children go out of their home environments and begin to socialize. The environment which the child interacts during the socialization process offers many opportunities for the child to become researchers and individuals open to exploration. These opportunities can affect children's development in both positive and negative ways. Today, technological devices are among the primary means by which children interact in the external environment (Yeygel \& Temel Eğinli, 2009). Easy accessibility, portability, and personalization features of technological devices ensure that children play a supportive element in the learning process. However, children who interact with technological devices too much experience problems such as withdrawal from the social environment, introversion, lack of communication, and distraction (Çelen, Çelik, \& Seferoğlu, 2011). Although technological devices contribute to children's access to information and doing exercises, the excessive and uncontrolled use of technological devices negatively affects the development of the child. To illustrate, while children used to play outdoor games in environments that would help them develop friendship and support their development, nowadays, with the introduction of technological devices, children have less time to play outside and establish social relationships (Arnas, 2005; Tuncer, 2000).

There is a significant correlation between children's level of interaction with technological devices and families' attitudes (Terkan \& Taylan, 2010). Shih (2003) stated that there is a correlation between family attitude and internet addiction. The wrong attitudes of families cause negative consequences for the child (Yalçın \& Duran, 2017). For example, due to the possible dangers of the internet, it is seen as a wrong and ineffective behavior for families to ban internet use for their children. Raising the awareness of families about the use of technological devices and internet is considered important in this respect (Odabaşı, Çoklar, \& Kavakçı, 2007; Tokel, Başer, \& İ̧̧ler, 2013).

Unhealthy domestic relationships cause an increase in the use of the internet and technological devices by children. A study conducted in China concluded that children of families who do not care enough for their children are internet addicts (Ayas \& Horzum, 2013). In a research of Bayraktutan (2005), he stated that mothers and fathers could not spare enough time for their children due to their busy business lives; therefore, children spend the time on technological devices that they are ideally supposed to spend with their parents and try to meet their "socialization needs" in virtual environments. Similarly, Whang, Lee, \& Chang (2003) found in their studies on internet addiction that individuals with internet addiction have high levels of loneliness, and being alone increase their level of internet addiction. As a solution, he stated that using internet should be controlled from the first years of life, and families should spend quality time with their children (Ayas \& Horzum, 2013; Bölükbaş, 2003).

After the family, the external environment with which the child interacts the most is educational institutions. For this reason, teachers have an important role in the prevention of technology addiction as well as families (Arslan, Bütün, Doğan, Dağ, Serdarzade, \& Arıca, 2010). Misuse of technological devices in the first years of life can cause undesirable and permanent results. Therefore, families and stakeholders involved in the education process should provide awareness of the prevention of technology addiction (Kuşkonmaz, 2011; Lee \& Chae, 2007). One of the most important devices that families and educators can use to convey correct information to children is illustrated children's books (Güzelyurt, 2020). With the help of illustrated children's books, how and how long technological tools will be used, and the problems that may occur in their misuse can be conveyed to children in accordance with their developmental levels. According to Sever (2015), the correctness of the content and the way of conveying the content through illustrated children's books are seen as a requirement for the message to reach its purpose.

In this respect, the study was carried out to examine the content of illustrated children's books that cover the subject of technology addiction for the preschool period. The study is considered important in terms of supporting the writing, publishing, and selection of high-quality illustrated children's books related to the prevention of technology addiction. However, no studies carried out on the subject of technology addiction in illustrated children's books were found. For this reason, it is thought that the study will contribute to the literature and will guide families and teachers in choosing and using illustrated children's books.

In this research, answers to the following questions were sought:

1. Which situations are included in the content of illustrated children's books on technology addiction for the preschool period?

2. What is the relevance of the content of the illustrated children's books on technology addiction for the preschool period with the literature?

\section{METHOD/MATERIALS}

In this part of the research, information about the research model, study group, data collection, and analysis are included.

\section{Research Model}

Please The study aimed to determine the status of illustrated children's books in terms of including the subject of technology addiction. For this purpose, the document analysis method, one of the qualitative research methods, was used. Document review covers the analysis of written materials that contain information about the phenomenon or facts aimed to be investigated (Yıldırım \& Şimşek, 2013). 


\section{Study Group}

The study group consisted of 15 illustrated children's books, the first editions between 2010 and 2019, determined by criterion sampling method, one of the purposeful sampling methods. Criterion sampling is the process of selecting the study group from the materials related to the subject to be researched and that meet research criteria (Merriam, 2013). In this study, the criterion was the books containing technology addiction (television, tablet, phone, computer) which were written for the preschool period. The research was also limited to illustrated children's books that are still in print and accessible to researchers.

\section{Data Collection and Analysis}

The words preschool, television, tablet, computer, mobile phone, technology, and internet were searched in the catalogs of libraries and on online websites selling books to identify the books related to the scope and content of the research. 72 illustrated children's books determined by this method were examined, and after the reading process, the illustrated children's books that did not fit the scope of the study were removed from the study group. 15 illustrated children's books were analyzed by two independent researchers who found the books to meet the criteria. Illustrated children's books were analyzed with the descriptive analysis technique and content analysis technique. The data obtained through the descriptive analysis technique are summarized and interpreted within the framework of the previously determined research subject or themes (Yıldırım \& Şimşek, 2013). Accordingly, the state of including technology addiction in illustrated children's books was examined in the study. Content analysis is defined as any qualitative data reduction and interpretation attempt to determine the voluminous qualitative material, its basic consistencies and meanings (Patton, 2014). The content analysis technique is used to identify common points in the content of many documents. In the content analysis, important concepts are determined, classified, and an interpretation providing generalization is obtained. In the research, categorical analysis was preferred among the content analysis techniques. A categorical analysis is subjecting the determined categories to frequency analysis (Büyüköztürk, Çakmak, Akgün, Karadeniz, \& Demirel, 2015). Accordingly, the codes with the theme determined in the research are expressed as frequency. The books are specified with codes (B1, B2, B3...). All of the illustrated children's books examined in the study were analyzed by two field experts. As a result of this, the codes with a consensus and disagreement were determined among the detected codes. To find the reliability ratio among the detected codes, the consensus formula designed by Miles \& Huberman (1994) was used. The reliability coefficient among coders was found to be .84 . Yıldırım \& Şimşek (2013) stated that a reliability percentage of at least $70 \%$ should be reached among coders. Accordingly, it can be said that the analysis results of the data obtained in the study are reliable.

\section{FINDINGS}

In this part of the research, the data obtained are presented. The data in this study were grouped under six themes: "Information on the books examined" has been grouped under six themes: "technological tools," "actions," "adverse situations," "noticing," and "prevention method.

\section{Theme 1: Demographic Information of the Books Reviewed}

Demographic information of the illustrated children's books examined in the study was discussed under this theme. The codes related to this theme, the original first edition year of the illustrated children's books, the first edition year in Turkish, the age recommendation, and findings regarding the family information note are given in Table 1.

Table 1. Findings regarding the demographic characteristics of the illustrated children's books examined

\begin{tabular}{lcccc}
\hline Code & Year of Printing in Original Language & First Edition Year in Turkish & Age Recommendation & Information for the Family \\
\hline B1 & - & 2010 & Available & Not Available \\
B2 & 1984 & 2011 & Not Available & Not Available \\
B3 & 2010 & 2011 & Not Available & Not Available \\
B4 & 2012 & 2012 & Not Available & Not Available \\
B5 & 2005 & 2012 & Not Available & Not Available \\
B6 & 2000 & 2013 & Not Available & Not Available \\
B7 & - & 2013 & Not Available & Not Available \\
B8 & 2013 & 2014 & Not Available & Available \\
B9 & - & 2014 & Not Available & Not Available \\
B10 & - & 2015 & Not Available & Available \\
B11 & - & 2015 & Available & Not Available \\
B12 & 2016 & 2017 & Not Available & Not Available \\
B13 & - & 2017 & Not Available & Available \\
B14 & - & 2019 & Not Available & Available \\
B15 & - & 2019 & Not Available \\
\hline
\end{tabular}

The illustrated children's books examined within the scope of the research were the books translated into Turkish ( $f=7)$ and the books originally written in Turkish $(f=8)$. There was no age recommendation $(f=14)$ and information note for the family $(f=11)$ in the illustrated children's books. 
Theme 2: Technological Devices

Technological devices in the illustrated children's books examined in the study were discussed under this heading. The data obtained regarding this theme are given in Table 2.

Table 2. Technological devices used

\begin{tabular}{lcl}
\hline Code & Frequency (f) & Books (B) \\
\hline Television & 6 & B1, B2, B4, B5, B6, B11 \\
Computer & 3 & B3, B7, B8 \\
Tablet & 3 & B10, B14, B15 \\
Phone & 1 & B13 \\
All & 2 & B9, B12 \\
\hline
\end{tabular}

The content of the examined illustrated children's books included technological devices such as television ( $f=6)$, computer $(f=3)$, tablet (3), phone $(f=1)$, and all $(f=2)$. Accordingly, it was observed that television as a device was frequently included in these books.

\section{Theme 3: Actions}

The actions taken through technological devices in the illustrated children's books examined in the study were discussed under this heading. The data obtained regarding this theme are given in Table 3.

Table 3.Action carried out through the technological device

\begin{tabular}{lcl}
\hline Code & Frequency (f) & Books (B) \\
\hline Playing games & 8 & B3, B7, B8, B10, B12, B13, B14, B15 \\
Watching cartoons & 7 & B1, B2, B4, B5, B6, B11, B13 \\
Using the Internet & 2 & B3, B13 \\
Watching TV series & 1 & B9 \\
\hline
\end{tabular}

The actions taken through technological devices in the examined illustrated children's books were observed as follows: playing games $(f=8)$, watching cartoons $(f=7)$, using the Internet $(f=2)$, and watching TV series $(f=1)$. Accordingly, it can be expressed that in these books, children mostly used technological tools as a means of playing games and watching cartoons.

In the illustrated children's book coded B8, the statements "...Yes, you heard right, video games. All the games you can think of. Hakan could not stop himself from constantly playing these games. The truth is, he couldn't even think of anything but video games," are included (Moore \& Mazalı, 2014).

In the illustrated children's book coded B9, the statements "...I got away from the computer and came to the hall. While my mom and dad were chatting at dinner, I got caught up in the TV series" are included (Oy, 2014).

In the illustrated children's book coded B11, the statements "...The sound of the television was wide open. A knight cartoon was playing on the screen. Limin and Zeytin were watching the cartoon on the one hand and imitating the ones in the movie on the other," are included (Elkorek, 2015).

In the illustrated children's book coded B13, the statements "...You know that you sometimes want to watch the cartoons you love to watch on the video channels on the internet, or you connect to other cartoons after that cartoons are over, and some of them are too scary that you don't want to watch them or they can be on subjects you should not watch. But you still watch them with curiosity and learn things that are not true, or you may be too scared of!" are included (Oy, 2017).

\section{Theme 4: Adverse Situations}

The adverse situations caused by the technological devices in the examined illustrated children's books were discussed under this heading. The data obtained regarding this theme are given in Table 4.

Table 4. Adverse situations caused by technological devices

\begin{tabular}{lcc}
\hline Code & Frequency $(\mathrm{f})$ & Books (B) \\
\hline Not playing sociable games & 12 & B1, B2, B3, B4, B5, B6, B8, B10, B11, B12, B14, B15 \\
Getting away from friends & 9 & B1, B2, B3, B5, B6, B8, B10, B12, B15 \\
Eating in front of the television & 8 & B1, B2, B4, B5, B6, B9, B10, B15 \\
Developing health problem(s) & 6 & B1, B7, B9, B10, B13, B15 \\
Family's being a negative role model & 6 & $\mathrm{~B} 2, \mathrm{~B} 3, \mathrm{~B} 6, \mathrm{~B} 9, \mathrm{~B} 10, \mathrm{~B} 11$ \\
Getting scared & 5 & $\mathrm{~B} 6, \mathrm{~B} 7, \mathrm{~B} 8, \mathrm{~B} 10, \mathrm{~B} 13$ \\
Not being able to fulfill responsibilities & 3 & $\mathrm{~B} 8, \mathrm{~B} 9, \mathrm{~B} 15$ \\
Encountering dangerous content on the internet & 2 & $\mathrm{~B} 3, \mathrm{~B} 13$ \\
\hline
\end{tabular}

The negativities caused by technological devices in the illustrated children's books reviewed were reflected upon the content in the form of playing games on technological devices ( $f=12)$, getting away from friends $(f=9)$, eating in front of the television/not 
wanting to eat anything $(f=8)$, developing health problem $(s)(f=6)$, the family's being a negative role model $(f=6)$, fear $(f=5)$, failure to fulfill their responsibilities ( $f=3)$, and encountering dangerous content on the internet $(f=2)$.

In the illustrated children's book coded B6, the statement "...Kokozu suddenly appeared on the screen. She looked very angry. That big rabbit made a lot of noise, I'll teach him a good lesson. Zipır was afraid. He pressed the buttons on the remote to turn the $T V$ off, but that didn't work at all. The knight drew his long sword and jumped out off the screen. Kokozu was attacking the Super Rabbit. They destroyed the table, chairs, and flowers. The hall was in a mess. Zipır was very scared. He ran to his room to hide. My mom! Help me! Zipır shouted so strongly that he awoke to his voice. His mother had come to him. You had a nightmare, dear. Yes, it's a terrible nightmare because you watch TV too much," are included (Lamblin, 2013, 11-14.)

In the illustrated children's book coded B7, the statement "...Fortunately it was all a dream. If I told you, you would be very scared too." is included (Çiçek \& Koruklu, 2013, 13).

In the illustrated children's book coded B8, the statements "...Startled Hakan got up and ran to the mirror. He expected to see himself aged, covered in spider webs, but no, it was all just a dream. Hakan was so relieved! "Happy birthday Hakan," his mother said, handing over her gift. Come on, what are you waiting for? Unwrap it! Hakan carefully unwrapped the gift and couldn't believe his eyes when he saw what was inside. Her mother had bought the game he had seen in his dream the night before. Hakan looked around in fear, knowing that the video vampires were waiting to act. This time I won't let them, he thought," are included (Moore \& Mazalı, 2014, 27-28).

In the illustrated children's book coded B13, the statement "...Would you like to wear glasses with lenses like binoculars?" is included (Oy, 2017, 6-7).

\section{Theme 5: The State of Being Recognized}

The recognition of the damages caused by the excessive use of technological devices in the analyzed illustrated children's books was presented under this heading. The data obtained regarding this theme are given in Table 5.

Table 5. Recognizing the damages caused by excessive use of technological tools

\begin{tabular}{lcc}
\hline Code & Frequency (f) & Books (B) \\
\hline The breakdown of the technological device/Depletion of the energy source & 8 & B1, B2, B3, B5, B11, B12, B14, B15 \\
One of the family members' recognizing the issue & 5 & B2, B3, B4, B10, B13 \\
Experiencing fear (dream, eyeglasses, zombie, monster) & 5 & B6, B7, B8, B10, B13 \\
The child's developing health problem(s) & 3 & B1, B9, B10 \\
\hline
\end{tabular}

In the illustrated children's books examined, it was observed that the damages caused by the excessive use of technological devices are noticed through the breakdown of the technological device/depletion of the energy source $(\mathrm{f}=8)$, one of the family members' recognizing the issue $(f=5)$, the fear of the child $(f=5)$ and the child's developing health problem $(s)(f=3)$.

In the illustrated children's book coded B1, the statements "...One day the television broke down; Mali's favorite cartoon started to look blurry. We took the TV to the maintenance service for repair. "This is solid. You had better get Mali to the doctor," he said," are included (Kozikoğlu, 2010).

In the illustrated children's book coded B2, the statements "... When Brother and Sister stepped off the school bus, they burst into the kitchen without even saying hello. Then they did something they did every day: they took their glass of milk and cookies into the living room and turned on the TV. "No doubt about it," thought Anne. The kids watch TV too much!" are included (Berenstain \& Berenstain, 2011).

In the illustrated children's book coded B8, the statements "... Hakan carefully unwrapped the gift and couldn't believe his eyes when he saw what came out of it. His mother had bought the game he had seen in his dream the night before. Hakan looked around in fear, knew that the video vampires wanted to act." are included (Moore \& Mazalı, 2014).

In the illustrated children's book coded B10, the statement "...Look, your eyes turned red, your fingers blistered," is included (Artukmaç \& Sürücü, 2015).

\section{Theme 6: Prevention Method}

The method of preventing technology addiction included in the illustrated children's books, was discussed under this heading. The data obtained regarding this theme are given in Table 6.

Table 6. Method of preventing technological addiction

\begin{tabular}{lcc}
\hline Code & Frequency (f) & Books (B) \\
\hline Playing games with friends & 6 & B1, B2, B3, B4, B6, B15 \\
Time limitation/Agreement/Controlled use & 6 & B2, B3, B4, B10, B13, B14 \\
Spending time with the family/the family's being a positive role model & 4 & B2, B3, B9, B13 \\
Quitting because of fear & 3 & B6, B7, B8 \\
\hline
\end{tabular}

In the illustrated children's books examined, it was found that technological addiction was prevented by playing games with friends $(f=6)$, time limitation/controlled use $(f=6)$, spending time with the family/the family's being a positive role model $(f=4)$ and fear $(f=3)$. It has been observed that it has been studied. 
In the illustrated children's book coded B8, the statements "...Sounds scary, right? It is. Just like vampires in horror movies, video vampires absorb actors' time and energy, making them expressionless faces and empty eyes. It makes them forget about homework and friendship. The only way to get rid of video vampires is to stop playing games altogether or limit play time. Well, easier said than done, of course," are included (Moore \& Mazalı, 2014).

In the illustrated children's book coded B10, the statements "...It also takes a lot of time. Let's specify a certain time limit for this," are included (Artukmaç \& Sürücü, 2015).

In the illustrated children's book coded B13, the statements "...For example, let's go to the movies as a family. I think it is more enjoyable to laugh or think together" are included (Oy, 2017).

In the illustrated children's book coded B15, the statement "...From now on, he decided to spend more time with his friends and use his tablet properly and adequately" is included (Yeşilay, 2019, 24-25).

\section{DISCUSSION, CONCLUSION AND RECOMMENDATIONS}

The study where the content of illustrated children's books that comprise the subject of technology addiction based on preschool period was examined. Also, what situations in the context of technology addiction were included in the mentioned books and the compliance of these situations with the literature were discussed. It was observed that TV, computer, tablet, and phone were respectively the most frequently included technological devices in the content of the books on technology addiction. Studies revealed that children have recently spent a long time on phones and tablets as much as they do on television (Ateş \& Saltalı, 2019; Kızıltaş \& Ertör, 2018). In this respect, it can be mentioned that the use of phones and tablets is less frequently mentioned in illustrated children's books.

When children took the actions on technological devices in illustrated children's books are examined, it was observed that children mostly performed the act of playing games and watching cartoons. Although the content covered in illustrated children's books is compatible with the literature, it cannot be sufficient. When children use technological devices, they also access the internet (Bükre, Özlem \& Deniz, 2017; Tuncer, 2000). Accordingly, the fact that very few books examine the situation of children encountering harmful content on the internet has caused the inadequacy of published illustrated children's books in terms of covering technology addiction with all its dimensions.

It can be pointed out that technology addiction has many effects on children. The most important effects of technology addiction on children are health problems, not playing games, getting away from friends, decreased family communication, and experiencing anxiety and fear (Altınkılıç, 2014; Özkılıç Kabul, 2019). It can be mentioned that there is parallelism between the negativities included in illustrated children's books analysed and the literature. Despite the fact that illustrated children's books cover many issues on technology addiction, it is one of the issues that should be discussed that illustrated children's books do not contain enough content about the dangers of the internet and virtual world to which children are frequently exposed. In addition, it can be said that there are some problems in the way these negativities are passed on to the child. To illustrate, some illustrated children's books include the content that children will see bad monsters if technological devices are used too much. Such expressions should not be used as they may cause anxiety and fear among children; instead, expressions suitable for children's development should be preferred.

The state of noticing technology addiction in illustrated children's books has occurred through undesirable situations such as the breakdown of the technological device, experiencing health problems, or the state of child's getting scared. In very few illustrated children's books, one of the family members noticed the state of the problem. It should not be overlooked that the use of expressions blaming family and children in the content of the books or the contents that make readers think this may negatively affect family-child communication.

In the conclusion part of illustrated children's books that include technology addiction, methods such as directing the child to play, increasing communication within the family, playing with technological devices in a controlled and time-limited manner were preferred as a solution. It can be mentioned that these methods are widely used methods when the literature was examined. Although the methods determined for the solution were desired, it cannot be said that they were sufficiently included in illustrated children's books. Moreover, book contentsreach a solution through the act of fear that the child will experience anxiety. According to the studies conducted, the most important role in technology addiction was family members being positive role models (Ertemel \& Aydın, 2015). In the illustrated children's books within the scope of the research, it was stated that family members also frequently used technological devices instead of spending time with the child. However, although the problem was solved for the child, it was observed that several parents continued to use technological devices in most of the books. In this context, it is not fair to say that the problem-solving process was done adequately and correctly in technology-themed illustrated children's books.

Technology addiction is among the issues that families have difficulty transferring to children and finding solutions (Çetinkaya, 2019). The information note and age recommendation for the families in the books about how to convey these issues through illustrated children's books or the ones that need attention is an important factor in achieving the aim of the book. When the illustrated children's books within the scope of the research were examined, it was determined that there was an age recommendation in only one illustrated children's book and an information note for the family in four illustrated children's books. In this respect, it can be pointed out that the examined illustrated children's books were not sufficient in terms of guiding families 
and supporting them to choose suitable children's books in accordance with the age of the child. As a result, it was concluded that illustrated children's books on technology addiction were not sufficient to cover the negative effects of technology addiction, the state of being recognized, and problem-solving. Illustrated children's books, which contain expressions appropriate to the developmental characteristics of preschool children, is one of the most important elements that would enable the child to internalize messages (Sever, 2015). It can be mentioned that there was no information note and age recommendation for the family in illustrated children's books, which is one of the important obstacles for the books to reach their goals. In this respect, the characteristics that illustrated children's books covering technology addiction are required to possess both in terms of quality and other factors should be developed in terms of technology addiction in the light of today's conditions.

In line with this information, the following suggestions can be made;

- Expressions that create anxiety, stress, fear, and expressions that blame the family or the child should be avoided in illustrated children's books on technology addiction.

- Published illustrated children's books should be updated in line with the developmental characteristics of the child, and new illustrated children's books should be written accordingly.

- To guide parents, information notes and age recommendations can be included in illustrated children's books.

- While writing children's picture books on technology addiction, current researches, studies, and new approaches can be used.

- In the process of writing illustrated children's books on technology addiction, experts in the field can be consulted.

\section{Declaration of Conflicting Interests}

The author(s) declared no potential conflicts of interest with respect to the research, authorship, and/or publication of this article.

\section{Funding}

The author(s) received no financial support for the research, author-ship, and/or publication of this article.

\section{Statements of publication ethics}

I/We hereby declare that the study has not unethical issues and that research and publication ethics have been observed carefully.

\section{Researchers' contribution rate}

The study was conducted and reported with equal collaboration of the researchers.

\section{Ethics Committee Approval Information}

Name of the board that made the ethical evaluation: Şırnak University Ethics Committee Chairman

Date of ethics review decision: 31/12/2020

Ethics assessment document issue number: 2020/65

\section{REFERENCES}

Akduman, G. G. (2011). Okul öncesi eğitimin tanımı ve önemi. G. Uyanık Balat (Ed.). Okul Öncesi Eğitime Giriş içinde (s. 1-18). Ankara: Pegem Akademi.

Altınkılıç, Z. (2014). Televizyon izlemenin 1-6 yaş çocuk sağlı̆̆ı üzerindeki etkilerine yönelik annelerin tutum ve davranışlarının belirlenmesi. izmir Dr. Behçet Uz Çocuk Hast. Dergisi, 4(3), 186-194.

Arnas, Y. A. (2005). 3-18 yaş grubu çocuk ve gençlerin interaktif iletişim araçlarını kullanma alışkanlıklarının değerlendirilmesi. The Turkish Online Journal of Educational Technology, 4(4), 59-66.

Arslan, E., Bütün, P., Doğan, M., Dağ, H., Serdarzade, C., \& Arıca, V. (2010). Çocukluk çağında bilgisayar ve internet kullanımı. İzmir Dr. Behçet Uz Çocuk Hast. Dergisi, 4(3), 195-201.

Ateş, M. A., \& Saltalı, N. D. (2019). KKTC'de yaşayan 5-6 yaş çocukların tablet ve cep telefonu kullanımına ilişkin ebeveyn görüşlerinin incelenmesi. Gazi Eğitim Bilimleri Dergisi, 5(1), 62-90.

Ayas, T., \& Horzum, M. B. (2013). İlköğretim öğrencilerinin internet bağımlılığı ve aile internet tutumu. Türk Psikolojik Danışma ve Rehberlik Dergisi, 4 (39), 46-57.

Bayraktutan, F. (2005). Aile içi ilişkiler açııından internet kullanımı. Yayınlanmamış yüksek lisans tezi, İstanbul Üniversitesi, İstanbul.

Bölükbaş, K. (2003). İnternet kafeler ve internet bağımlıı̆̆ı̈ı̈zerine sosyolojik bir Araştırma: Diyarbakır örneği. Yayınlanmamış yüksek lisans tezi, Dicle Üniversitesi, Diyarbakır.

Bükre, Ç., Özlem, S., \& Deniz, Ç. (2017). Adı: merakı, soyadı: çocuk, durum: çevrimiçi, sonuç: grooming, internette çocuk istismarı. Journal of Current Pediatrics/Guncel Pediatri, 15(3), 87-97.

Büyüköztürk, Ş., Çakmak Kılıç, E., Akgün, Ö. E., Karadeniz, Ş., \& Demirel, F. (2015). Bilimsel araştırma yöntemleri (19. Baskı). Ankara: Pegem Akademi.

| Kastamonu Education Journal, 2021, Vol. 29, No. 21 
Çelen, F. K., Çelik, A., \& Seferoğlu, S. S. (2011). Çocukların internet kullanımları ve onları bekleyen çevrim-içi riskler. Akademik Bilişim Konferansında sunulan bildiri, İnönü Üniversitesi, Malatya, Erişim adresi: https://ab.org.tr/ab11/ozet/172.html

Çetinkaya, S. (2019). Algılanan anne baba tutumlarının ergenlerde akıllı telefon bağımlıı̆ı ile ilişkisinin incelenmesi. Yayımlanmamış yüksek lisan tezi, İstanbul Sabahattin Zaim Üniversitesi, İstanbul.

Ertemel, A. V., \& Aydın, G. (2018). Dijital ekonomide teknoloji bağımlılığı ve çözüm önerileri. The Turkish Journal On Addictions, 5(4), 665690.

Güzelyurt, T. (2020). Okul öncesi dönemde cinsel eğitim ve cinsel istismardan korunma: Resimli çocuk kitaplarına yönelik bir inceleme. Uluslararası Çocuk Edebiyatı ve Eğitim Araştırmaları Dergisi (ÇEDAR), 4(1), 54-69.

Kızıltaş, E., \& Ertör, E. (2018). Okul öncesi eğitim alan çocukların akıllı telefon kullanımı ile ilgili aile görüşlerinin incelenmesi. Uşak Üniversitesi Eğitim Araştırmaları Dergisi, 4(2), 1-18.

Kuşkonmaz, H. (2011). İlköğretim okullarındaki öğretmenlerin mobil öğrenmeye yönelik algı düzeylerinin belirlenmesi. Yayımlanmamış doktora Tezi, Bahçeşehir Üniversitesi, İstanbul.

Lee, S. J., \& Chae, Y. G. (2007). Aile bağlamında çocukların İnternet kullanımı: aile ilişkileri üzerindeki etkisi ve ebeveyn arabuluculuk. Cyber Psychology ve Davranış, 10(5), 640-644.

Merriam, S. B. (2013). Nitel araştırma: Desen ve uygulama için bir rehber. Ankara: Nobel Yayıncılık.

Miles, M. B., \& Huberman, A. M. (1994). Qualitative data analysis: An expanded source book. Thousand Oaks: Sage Publications.

Odabaşı, H. F., Çoklar, A. N., \& Kabakçı, I. (2007). Yeni dünya: Internet-ailelerin yeni dünyadaki sorumlulukları nelerdir?. 8. Aybastı-Kabataş Kurultayında sunulan bildiri. Anadolu Üniversitesi, Eskişehir, Erişim adresi: https://docplayer.biz.tr/3469936-8-aybasti-kabatas-kurultayi.html

Özkılıç Kabul, N. D. (2019). Üç yaş çocuklarda teknolojik alet kullanımının sosyal beceri, oyun becerisi ve dil gelişimi üzerindeki etkilerinin incelenmesi. Yayımlanmamış doktora tezi, Maltepe Üniversitesi, İstanbul.

Patton, M. Q. (2014). Nitel araştırma ve değerlendirme yöntemleri. M. Bütün ve S.B. Demir (Ed.). Ankara: Pegem A Yayıncılık.

Sever, S. (2015). Çocuk ve edebiyat. İzmir: Tudem Yayınları.

Shih, S. R. (2003). Network characteristics of the virtual world and its influence on the young. Student Counseling Bimonthly, 89, 80-89.

Terkan, N. \& Taylan, A. (2010). Internet ve çocukların korunması: Ebeveyn kontrolü. 2. Uluslararası Yeni Illetişim Ortamları ve Etkileşim Konferansı. Marmara Üniversitesi. İstanbul, Erişim adresi: https://www.researchgate.net/publication/230608001_Child_ Protection_and_the_Internet_Parental_Control

Tokel, S. T., Başer, D., \& İ̧̧ler, V. (2013). Türkiye'deki ebeveynlerin çocuklarının internet ve sosyal paylaşım siteleri kullanımına yönelik bilg seviyeleri ve algıları. Mersin Üniversitesi Eğitim Fakültesi Dergisi, 9(1), 225-236.

Tuncer, N. (2000). Çocuk ve internet kullanımı. Türk Kütüphaneciliği, 14(2), 205-212.

Yalçın, H., \& Duran, Z. (2017). Çocukların iletişim araçları ve internet kullanma durumu ile aile-çocuk internet bağımlılık düzeyleri. Electronic Turkish Studies, 12(23), 219-236. http://dx.doi.org/10.7827/TurkishStudies.12052.

Yeygel, S., \& Temel Eğinli, A. (2009). Çocukların yeni oyuncağı: İnternet (Çocukların internet kullanımına ilişkin bir araştırma). Marmara iletişim Dergisi, (15), 160-183.

Yıldırım, A., \& Şimşek, H. (2013). Sosyal bilimlerde nitel araştırma yöntemleri. Ankara: Seçkin

Whang, L., S., Lee, S., \& Chang, G. (2003). Internet over-users' psychological profiles: A behavior sampling analysis on internet addiction. Cyberpsychology \& Behavior, 6(2), 143-150.

\section{Children's Books Included in the Research}

Artukmaç, Y., \& Sürücü, Ö. (2015). Teo'nun tablet kitabı. Ankara: Bilgi Yayınevi.

Berenstain, J., \& Berenstain, M. (2011). Berenstain ayıları-Bilgisayar belası. İstanbul: Mikado.

Berenstain, J., \& Berenstain, S. (2011). Berenstain ayıları-Fazla televizyon seyretmek. İstanbul: Mikado.

Çiçekler, Y., \& Koruklu, Ö., (2013). Yıldız'la sohbet eğitimi 4 -Bilgisayar canavarı. İstanbul: Çamlıca Çocuk Yayınları.

Deredel Rogeon, S. (2012). Atakan televizyon seyretmek istiyor. İstanbul: Kaknüs.

Elkorek, N. (2015). Limon ile Zeytin-TV. İstanbul: Mart Yayınları.

Kozikoğlu, T. (2010). Bir çizgi film daha! Mali. İstanbul: İletişim Yayınları.

Lamblin, C. (2013). Zıpır sürekli televizyon izliyor. İzmir: Uçan Balık.

McDonnell, P. (2017). Modern mağara çocuğu Tek. İstanbul: Beyaz Balina.

Moore, J., \& Mazalı, S., (2014). Video oyunlarında aşırıya kaçınca. İstanbul: Remzi Kitapevi.

Oy, A. (2017). Telefon istiyorum!-Pedagojik öyküler dizisi 27. İstanbul: Mandolin.

Oy, A. (2014). Ekrana yapışan çocuk-Pedagojik öyküler dizisi 19. İstanbul: Mandolin.

Özen Açıl, Y. (2019). Tablet Tobi. İstanbul: Abaküs.

Petingi, A. (2012). Cemile çok fazla televizyon seyrediyor. İstanbul: Kaknüs

Yeşilay (2019). Ece'nin karne hediyesi-Efe'nin tableti. İstanbul: Yeşilay Yayınları. 